\title{
Influences of Viral Marketing in Social Networking Sites ON CONSUMERISM
}

\author{
Wong, Krystle Jiajing \\ UCSI University \\ krysjwong@gmail.com
}

\begin{abstract}
Social networking sites (SNS) being a widely used online interaction tool have led to the widespread of online marketing strategies such as viral marketing. While interacting on SNSs, SNSs users tend to need to portray an ideal self to gain positive social feedback Hence, the need to consume and purchase products or restaurants food and beverages that are promoted on viral marketing posts. Limited literature has studied viral marketing through SNS and consumerism. Therefore, this study aims to look into factors influencing consumerism in the context of viral marketing on SNSs. The qualitative research method was implied based on Social Comparison Theory, Impulse Buying Theory, and Affluenza Compulsive Buying Theory. An interview was conducted on seven in-college youths in the area of Klang Valley. Four factors behind the influence of viral marketing in social networking sites on consumerism have been identified. They are e word of mouth (eWOM), visuals, content, and rating. Other than viral marketing, the study identified two more main factors that influence consumerism-psychological behaviour and brand offers. Two types of consumerism were also identified. This study provides an insight for SMEs on the low-cost viral marketing through SNSs which promotes consumerism through rapid response rate. Socially, consumerism is also related to bankruptcy. This study would be one of the pioneer studies in Malaysia which looked into consumerism through viral marketing on SNSs, contributing to local context literature as well as from the context of SNSs which was not thoroughly studied by past researchers. Limitations and future research were further discussed in the paper.
\end{abstract}

Keywords: Consumerism, Viral Marketing, Social Networking Site (SNSs), Youth Consumption, Self-Presentation, Malaysia

\section{INTRODUCTION}

Information sharing and social interactions among online communities and social networking sites (SNSs) are the reasons for the increase of online marketing nowadays (Hajli, 2014). One of the marketing strategies commonly used on social media by companies and brands is viral marketing. First introduced by Knight in 1996 (Phelps et al., 2004) viral marketing was defined as messages or content spreading through social media like a virus. It relies on consumers 
to virally share the information on their social media platforms to achieve marketing goals (Pescher et al., 2014). Viral marketing posts often generate a viral trend on SNSs which led to a new definition of success is made based on social approval, profile views, the number of followers, and validation (Leow, 2015).

It was suggested that two-thirds of people on social media post images to their profiles to make their lives seem more adventurous (Zulfagharifard, 2015). Most of them are youths. According to Nielsen Malaysia in 2016 (Casey, 2017), Malaysians averagely spent 2.8 hours daily on social media. Hence, using SNSs is the activity that topped the list of activities consumed via smartphones among Malaysians. A recent survey conducted in Monash University Malaysia and University of Malaya (UM) states SNSs such as Facebook, WhatsApp and Instagram are the top three most used SNSs among students in public and private universities in Malaysia (Sani, 2017). One of the popular activities via SNSs is passing on online viral content. It is positively related to the intensity of time spent online (Ketelaar et al., 2016). This activity is very much related to youth who have the highest internet usage.

Three theories were adopted to serve as a theoretical basis to support this study, which are Social Comparison Theory (Festinger, 1954), Impulse Buying Theory, and Affluenza Compulsive Social Comparison Theory suggests that the comparison between people exists when objective measures of performance are non-existent in the context to evaluate their opinions and performances (Nabi \& Keblusek, 2014). In the context of SNSs, when there is no objective measure of the performance of SNSs users on SNSs, individuals compare the likes, follows, shares, and comments received on their social media posts to evaluate their value on social media.

In assessing consumerism qualities such as impulse and compulsive buying, Stern's (1962) Impulse Buying Theory and Faber et al. (1987) Affluenza Theory of Compulsive Buying was applied in the study. This study looks into the category of Suggestion Impulse Buying which suggests that consumers generate the need to buy while in contact with the product (Stern, 1962) or in the context of SNSs, be evoked to purchase a certain product from images and comments through viral posts on online shops (Lo et al., 2016). Relating it to the study, social media users might not trigger the thought of purchasing a certain product until seeing it in viral posts shared by online peers on social networking sites.

On the other hand, the Affluenza Theory of Compulsive Buying suggests that the satisfaction obtained from purchasing goods brings away the negative thoughts about themselves (McQueen et al., 2014). For the context of this study, social media users have the urge to purchase products in the SNSs' viral marketing. Following this, social media users portray a positive self-presentation through their online identity as a part of the escapism mechanism. This study discusses the following objectives:

RO1 To examine how viral marketing in social networking sites influences consumerism.

RO2 To examine why viral marketing in social networking sites influences consumerism.

RO3 To examine which quality of consumerism (impulsive buying, compulsive buying, money, attitude, or others) are influenced by viral marketing on social networking sites.

RO4 To examine which quality of viral marketing on social networking sites influences consumerism. 


\section{LITERATURE REVIEW}

Viral Marketing in Social Networking Sites and Its Influences on Consumerism in Malaysia Context. High usage intensities are one of the major factors that motivate consumer's participation in a viral marketing campaign (Pescher et al., 2014). Statistics indicate that $67 \%$ of Malaysians are active users of social networking sites ("Communications and Multimedia Pocket Books of Statistics," 2015). While Malaysians averagely spend 20\% of their time on their phones using social media ("2016 Malaysia Digital Landscape," 2016), youths at the age range of 1524 especially have the most intensified social media usage in the nation (22.7\%) (Malaysian Communications and Multimedia Commission. 2014). As a result, youths in Malaysia are seen as the main targeted interviewees of this study.

\section{Self-Presentation on Social Media}

Social media users are often exposed to information from friends and acquaintances that they follow on social media (Erkan \& Evans, 2016). Social media users deem the need to control information that they share to present themselves with positive information on social media sites (Gonzales \& Hancock, 2011; Thoumrungroje, 2014).

The positive feedback generated by the positive information enhances the social media users' self-esteem (Thoumrungroje, 2014). Thus, the need to consume conspicuous goods to present an ideal self on SNSs. The consumption of conspicuous goods includes visiting and paying a premium price at restaurants that have gained a good reputation on social media (Kim et al., 2016). However, other than displaying positive information, negative emotions and dissatisfactions are also displayed through SNSs (Yen, 2016)

\section{Viral Marketing in Social Networking Sites}

In this digitalized society, the mass public relies highly on SNSs for decision-making (Hinz et al., 2011). The emergence of social media has also changed the marketing communication landscape, including viral marketing on SNSs. Viral marketing offers many benefits, such as low cost, and a high response rate to connect brands to consumers domestically and internationally (Yang et al., 2012). For these reasons, viral marketing has been commonly used in recent years.

Other than the official viral marketing produced by a brand, purchase intention is also influenced by various forms of social media posts by consumers including shared posts (Forbes, 2013). Hence, the trending viral marketing strategy among marketers. Specifically for youths, strategizing viral marketing places peers as an important factor of influence towards shaping youths' opinions and ideas (Niu, 2013).

\section{Consumerism}

Consumerism was categorized by scholars into three concepts, mainly scheming business motives, the rights of consumers, and an ideology (Yani-de-Soriano \& Slater, 2009, as cited in Al Kwifi \& Ahmed, 2015). While impulse buying is defined as purchase decisions made irrationally in favour of immediate possession, recreational compulsive buying is defined as a form of buying that improves the mood of individuals (Parakh et al., 2016). SNS shoppers are more compulsive than online shoppers when it comes to purchasing behaviour (Donthu \& Garcia, 1999, as cited in Chiu et al., 2014). 
Consumerism often brings out an individual's emotion. However, shopping motivations such as convenience and cost-saving have a larger impact on utilitarian products compared to hedonic products. The shopping motivations for hedonic products shopping are entertainment and a sense of gratification which are more related to emotion (Rahman et al. (2018). Based on the earlier evidence, the research objective was proposed:

\section{METHODOLOGY}

To further discuss in-depth the influences of viral marketing in SNSs on consumerism, the study uses a qualitative method of an in-depth interview in gathering data to explore more areas of interest (Wimmer \& Dominick, 2014). There were two phases of this interview; screening and in-depth interview. The screening phase using a survey was conducted to select the right targeted participants to be included in the in-depth interview. Data from the interview were analysed using thematic analysis.

Measurements. The screening phase used a survey to determine the fulfillment of the criteria set for an interview participant. The questionnaire items for self-representation were adapted from Seidman (2013) and Pounders et al. (2016). While the items for level of selfdisclosure were adapted from the Revised Self-disclosure Scale (RSDS) by Wheeless (1978) (Bronstein, 2013). The interview phase used a discussion guide consisting of 15 questions to assess the four research questions set.

Participants and sampling. The settings of this study revolved around undergraduates and the youth community in Klang Valley. The targeted population of this study is incollege youths around the demographic area of Klang Valley who have been identified as the heaviest SNSs users. Furthermore, Klang Valley has the highest percentage of social media users (29\%) in the nation (Malaysian Communications and Multimedia Commission. 2016). To select the participants, the study has used purposive sampling with specific criteria. The participants were identified from the screening phase. The criteria were possession of moderate to a high level of both self-presentation on social networking sites and disclosure of personal information online.

A combination of purposive sampling and snowball sampling was applied in this study. As purposive sampling technique chooses its participants due to the qualities that it possesses (Etikkan et al., 2016), Goodman (1961)'s snowball sampling generates its samples through a particular existing network, the first few participants of the study would be determined through purposive sampling which determines the interviewees through the qualities that they possess. Seven respondents age between 21 to 24 had been selected for an in-depth interview. The data collected has reached $90 \%$ of the study. Thus, met the data saturation requirement (Tran, Porcher, Falissard \& Ravaud, 2016).

\section{FINDINGS AND DISCUSSION}

This study has identified twelve themes that have been filtered and categorized into four variables that are viral marketing, psychological behaviour, brand offer and consumerism. The results of this study concluded that there are four dimensions behind the influences of viral marketing in social networking sites on consumerism. Additionally, two other main factors that also influence consumerism are psychological behaviour and brand offer. Psychological behaviour has two dimensions that are self-presentation and social comparison. 
While brand offer factor includes convenience and product. Besides that, two different types of consumerism were identified through the results of this study. They are impulsive and compulsive buying. The answers to the research objectives are discussed below:

\section{RO1: To examine how viral marketing in social networking sites influences consumerism.}

\section{E-Word of Mouth (e-WoM)}

As suggested by the results of the study, credibility of the source, circulation on SNSs and peer influence are among the E-WoM factors that influence consumerism. The credibility of the source is one of the main reasons why SNSs users are motivated to pass along certain content and as a result, creating an e-WoM for an intended message.

The credibility of a source is among the reasons why SNSs users are motivated to pass along certain content and as a result, creating e-WoM for an intended message. For example, viral marketing posts associated with Facebook pages that usually share about lifestyle trends, such as food and travel are viewed as a much more credible source than others. The results were somewhat consistent with past studies that SNSs users' engagement with a Facebook page could generate positive eWoM, brand awareness, and consumers' purchase intention (Hutter, Hautz, Dennhardt and Füller, 2013) as interviewees, responded that,

There is credibility since there are more reviews, like those pages that promote about the restaurant, they are more trustable.

- Interviewee M

Other than such Facebook pages, social media influencers are also considered a credible source that triggers e-WoM among SNSs users as respondents would mention that they would rely on,

...Posts that are shared by social media influencers or vloggers, because they take a lot of great looking pictures and talk about how good the food is.

- Interviewee Ce

The next factor is a high rate of referral numbers determines the effectiveness of a viral post. The results of this study were further proven that circulations on SNSs are among the viral marketing factors that influence consumerism (Kalyanam, McIntyre \& Masonis, 2007; Thorbjørnsen, Ketelaar, Van't Riet \& Dahlén, 2015). The majority of the respondents have indicated that the high frequency of circulation of a certain viral post among their social circle on SNSs would trigger their interest and curiosity towards the viral marketing post. Thus, trigger purchase intention. As mentioned by an interviewee:

Because I would like to see what the fuss is about. Especially if the posts are very interesting and everyone is talking about it, so I would want to join the bandwagon. 
The third factor motivating e-WoM on SNSs is peer influence. As indicated by the majority of respondents in this study, they are more likely to share a certain viral marketing post when the content was passed along by people that they are close with, such as family and friends. One of the most effective marketing strategies used by marketers today is online peer-to-peer on their target audience using viral marketing (Ketelaar et al., 2016). The trust towards online peers on SNSs significantly affects purchase intentions (Hajli, 2014). When a majority of peers have shown interest in a certain viral marketing trend or have taken part by visiting the restaurant or purchased the product, SNSs generate more interest towards the trend. Consumers also find it harder to resist an opportunity to consume with the company of their friends or when invited by their friends, as one of the respondents have mentioned that,

I would very likely go for it if it triggers my interest, no matter how far, but I need to have friends to go with. I would feel weird to go alone but when I go with a group of friends, it's different.

- Interviewee Ch

\section{Convenience}

The convenience of location, according to the findings, is of utmost importance for consumers when deciding on whether or not they would consume a particular product or visit a particular restaurant or café. The result is aligned with many research which suggested that the convenience of location is significant in increasing store patronage (Phan \& $\mathrm{Vu}, 2015)$. While not bearing as strong of significance, the convenience of time, promotions and deals, are among the factors considered by consumers before visiting a café or restaurant.

Furthermore, results by Jeravaza and Chitando (2013) concluded that consumers' traveling time towards the restaurant is the most important factor considered by consumers, before location convenience and service quality. The findings of this study further support the statement, highlighting that the proximity of location was among the most influential factors to influence consumers purchase intention as respondents would mention that,

It depends on the location of the restaurant/café.... I won't purposely make my way out for a far location.

- Interviewee M

\section{Product}

There are three main qualities of a product that affect the consumer's purchase interest. They are the nature of the product, originality, and uniqueness. Concerning the nature of the product, consumers' primary interest was in food, and travel lifestyle-related posts. While other materialistic products such as cosmetics, apparel, and others were secondary.

The second quality, product originality includes limited edition or places that may not be available for a visit in the future. For example, items on the menu that is only available for a limited period or physical items with limited availability. Consumers who tend to spend excessively are more easily influenced by product originality (Kukar-Kinney, Scheinbaum \& Schaefers, 2016). This originality motivates consumers' purchase intention as failing to purchase would lead to their disappointment. On contrary, Li, Zhang, and Wang (2015) suggested that the originality of the product has less influence on purchase decision compared to the product's usefulness. 
If it's something limited or things that I won't be able to try in the future, then I will feel disappointed.

I remember when Fenty Beauty released a limited-edition Galaxy set, I was genuinely disappointed knowing I will never be able to get my hands on it.

- Interviewee H

The third quality is the uniqueness of products such as cafés with unique settings. This uniqueness motivates purchase intention because it creates a good feeling for being a trendsetter through a positive self-presentation. This further supports findings by Bian and Forsythe (2012) which pointed the significance of the need for uniqueness in triggering the consumer's purchase intention. Thus, influence the financial performance of a product (McNally et al., 2010). As a response from an interviewee:

If I discovered someplace new and unique that it's not as viral on social media, I'd consider sharing it, because I like the feeling of being a trendsetter."

- Interviewee M

When it comes to items of their liking, some respondents confessed that they would also try out places that are not recommended by their peers, mentioning that,

For example, there was a viral café with Hello Kitty theme. I've heard from my friends that the food wasn't great, but because I'm a Hello Kitty fan, I still chose to go in the end."

- Interviewee Ce

\section{RO2: To examine why viral marketing in social networking sites influences consumerism.}

\section{Self-Presentation}

Findings suggest that while interacting on SNS platforms, social media users often need to express their ideal selves on SNSs. Self-presentation on SNSs is exercised through sharing appealing pictures to portray an ideal lifestyle, posting their life events, and filtering content to present a perfect life. To get a positive response from these posts, pictures posted are edited to look good. Consumers with low self-esteem have more need to present an ideal image, through impulsive buying and excessive spending (Khan \& Dhar, 2006; Thoumrungroje, 2014; Wilcox \& Stephen, 2013).

Likes, comments, and shares acquired from purchase posts enhance consumer's selfesteem. Hence, the need for impulsive buying to gain a positive response through SNSs posts. SNSs users tend to filter and present themselves with positive information to generate a positive social response from such (Ellison, Steinfield \& Lampe, 2007; Thoumrungroje, 2014; Valkenburg, Peter \& Schouten, 2006).

Most importantly, the photos must look good. It's a new era, people don't just post anything these days. It has to look good to be shared.

- Interviewee $\mathrm{Ch}$ 


\section{Social Comparison}

It was suggested by Xiang et al. (2016) that social media users tend to try and imitate a certain style, including fashion and lifestyle. The results further support the statement by suggesting that SNSs users need to imitate a socially accepted way of interacting on SNSs to make sure that they would gain a positive social response from posting such social media feeds. It was also suggested that after gaining positive feedbacks, SNSs users gain a sense of achievement which would motivate them to carry on social comparison with their social peers.

Findings of the study have also proved that SNSs users find the need to keep up with viral SNSs trends which in this case would be to post pictures of their visits to a certain café that was virally circulated on SNSs as doing so would generate positive social responses such as likes and shares. Those positive social feedbacks received often leave them with a sense of achievement and validation, with an overall righteous feeling that would increase their self-worth as one of the interviewees mentioned that,

I feel good about getting attention from a lot of people. This also motivates me to go for more trendy places, because of the envy for others that get a lot of "likes" on social media.

- Interviewee Ce

Such a sense of achievement and validation motivates the users to continue the social comparison with their social peers. Facebook is commonly used as a platform to compare with peers. Thus increases users' engagement of social comparison (Lee, 2014).

\section{RO3: To examine which quality of consumerism (impulsive buying, compulsive buying, money attitude, and others) are influenced by viral marketing on social networking sites.}

\section{Impulsive Buying}

In the context of SNSs, SNSs users generate an urge to purchase and consume through images and comments on viral posts for online shops and restaurants (Lin \& Lo, 2015; Lo, Lin \& $\mathrm{Hsu}$, 2016). Online marketers tend to manipulate the consumers' sense of vision through images such as the unique setting of a restaurant or café or a specialty product to stimulate their impulse buying. Hence, when the consumers get in contact with the stimulus (images, comments, viral posts, and others), impulse consumers commonly lose their rationality and very likely to perform impulse purchases (Chen, Su \& Widjajah, 2016).

Nevertheless, the results of this study suggest the presence of rationality and logical evaluation in the process of impulse buying. Although financial is not an important criterion in decision making, the interviewees could still rationally weigh the value of the product and convenience before making any purchase. This indicates that impulse buying still involves logical evaluation and is not necessarily irrational (Chen, Su \& Widjajah, 2016). Furthermore, impulse buying does not always result in actual impulsive buying when generating an urge to purchase or consume (Trandafilović et al., 2013).

Impulsive buying is easier to occur for lower price products, especially food that is generally cheaper than materialist items. Consumers do not mind going into trial and error, as mentioned: 
I feel that I'm more of a trial and error person... I'd rather go try it, if it's not good I'd just never come back.

- Interviewee N

This result suggests the process of impulse buying involves logical decisions due to financial constraints. However, products or restaurants that the consumers have high attachment with may attract impulsive buyers despite the financial constraint.

We realize most things on the menu are expensive. But because we still want to take pictures of it, so my friends and I will share the food (to split the cost).

- Interviewee $\mathrm{Y}$

On another note, the inability to purchase any product or visit any restaurant does not disappoint an impulse buyer. This is due to excessive options in the market, including the mushrooming restaurants in the Klang Valley that also serve almost similar menus. The consumers have alternatives of virally trending products or restaurants to visit, as stated:

There are so many trendy places out there, and since I can't go for all of them, I don't feel like I lost out on much if I didn't go for one or two of them.

- Interviewee Ce

\section{Compulsive Buying}

Researches from the past have often suggested that compulsive buying is associated with depressed and negative feelings and that the consumption of conspicuous goods would bring a sense of satisfaction that kills off the negative thoughts of oneself (McQueen, Moulding \& Kyrios, 2014). Despite that, the findings of this study offered a different point of view into the matters of compulsive buying in the context of viral marketing in SNSs as findings suggest that there is a stronger significance of compulsive buying through the need of self-pamper and self-reward after accomplishing certain challenging task or period.

Another characteristic is the social factor. For example, birthdays or gatherings with friends and family. Consumers' decisions to visit a particular restaurant or café are likely to be influenced by social factors such as their lifestyle. Many respondents have commented that they are more likely to make such visits or consumption during special occasions like birthdays. This could also be seen as a form of fear of missing out as they are reluctant to miss out on such occasions when invited by their peers. This finding is consistent with several past works of literature indicating that negative feelings are not the main reason behind compulsive buying, but also biological and social factors (Faber, 1992; Moschis, 2007a; Raab et al., 2011; Grougiou, Moschis \& Kapoutsis, 2015).

\section{RO4: To examine which quality of viral marketing on social networking sites influences consumerism.}

\section{Content}

Content is the most important quality in viral marketing posts. This study found that it is imperative for the contents to be adequately informative, credible, cater to consumer's interests, and portray many positive comments. 
The information provided has to be sufficient without requiring additional research to persuade the consumers to purchase the product or visit the restaurant. For instance, if a review article contains all information such as images, prices, ratings, the menu of the place, and others, consumers are more likely to compare their likings with the viral content and decide if it interests them and if they would decide to consume.

The credibility of the information is often perceived when it is shared by their family or peers. In terms of personal preference, consumers are commonly only interested in a viral post with content that matches their interest. For example, if they are more interested in food and travel related lifestyle content, they tend to take more notice of such content when coming across them on SNSs.

Results also suggested that consumers are fonder to viral posts that contain larger amounts of comments as suggested by Kim, Li \& Brymer (2016). The number of comments on SNSs does have a positive effect on a restaurant's financial performances as they concluded that consumers would happily spend more to visit restaurants that have been virally shared on SNSs, despite several bad reviews. For example, when the majority are interested in a virally trending restaurant, café, or item, and reacted in the comments section that they would love to try, while few tried and gave a bad review, consumers would still likely consume the product or visit the restaurant or café. The reason being would be that they are curious about what the hype is about and that the viral trend circulating a product or a restaurant would capture their interest. One of the responders stated that,

I'd still visit, but I won't have too much expectation on them, mostly because I'd feel curious about them. Curious because everyone is talking about it and I would like to know what the hype is all about.

- Interviewee M

\section{Rating}

The results suggested that consumers are more likely to get interested in a viral post with high ratings or fond reactions such as a high number of share rates and likes on SNSs posts. Similar to a study by Thorbjørnsen et. al (2015); the referral numbers from SNSs users to other potential consumers ultimately determine the success of the viral marketing post.

Besides that, consumers tend to associate brands or products, or in this context, viral marketing posts with more high ratings in the form of likes shares on SNSs to be more reputable and is more willing to purchase or consume the product or in the restaurant or café (Dehghani \& Turner, 2015). It was suggested by Chen et al. (2016) that like for certain posts indicates SNSs user's positive attitude or idea towards social media contents on SNSs. However, results suggest that the number of likes generally does not have a positive effect on consumerism as consumers often find that they are meaningless and unreliable. All respondents in this study stated their distrust over the likes, thus it is not a criterion of judgment for any SNS post. Sometimes they simply click for no reason. Hence do not see the reliability of the number of likes, as mentioned:

If it is things like likes and ratings, anyone can randomly click on it.

- Interviewee N 
Like likes or what, people might just like it because it looks nice.

- Interviewee Y

In conclusion, the number of likes generally does not have any positive effect on consumerism. They are identified as meaningless and unreliable, where the consumers do not rely on the number of likes for the purchase decision.

\section{Visuals}

Visuals are seen to be the quality of viral marketing that influences consumerism the most as this is an era of visuals. Findings have suggested that having appealing images and videos of a restaurant's ambiance or its food on a viral marketing post would most likely generate their interest in visiting the restaurant or café.

Appealing images are commonly shared through social community platforms (SCP) such as Instagram and have a larger influence on impulse buying compared to other SNSs platforms (Xiang et al., 2016). SCP is often used by social media influencers such as bloggers, vloggers, and others who can form an intimate relationship with their audience and followers (Korotina \& Jargalsaikhan, 2016). From this study, the impact played by the visuals posted or shared by the social media influencers was minor. Nevertheless, social media influencers are believed to have quite a huge impact $\mathrm{n}$ consumer's purchase intention, as mentioned by one respondent:

Usually (attracted to) posts that are shared by social media influencers or vloggers, they take a lot of great looking pictures and talk about how good the food is.

- Interviewee Ce

Compared to appealing images, the video does not contribute a strong effect on a purchase decision. Yet it is considered as a factor for consumerism, as stated by a respondent:

I had my friends and family telling me it wasn't worth the hype. Still, because the videos made the food look so good, and everyone in the comments was excited to try the food, I ended up going for it.

- Interviewee $\mathrm{H}$

Interestingly, consumers tend to imitate the appealing visuals seen on viral marketing posts when they exercise their purchase. The consumers see the visual as a trend on SNSs, hence imitate the same act and post the visuals on their SNSs. The act of imitation and posting on SNSs is a form of social comparison and peer influence due to the need to follow the trend. A respondent mentioned a statement that:

"Yes, if they have photos and videos to show how nice the place is, then I'll go. Photos are the main attractions. Like when you see people taking nice pictures at the place, candid pictures especially, it makes you want to go and take the same pictures to post on social media."

- Interviewee Ch 


\section{IMPLICATION}

Based on the Social Comparison Theory which suggested that when a guideline to measure a certain performance is non-existent, the comparison between people exists to evaluate their perceptions and performances (Nabi \& Keblusek, 2014). The findings on the theory further strengthen the Social Comparison Theory as in the context of SNSs, the objective measurement of performances is non-existent. As a result, when interacting on SNSs, SNSs users were concluded in this study to compare with their peers on SNSs to gain positive social response such as likes and shares that would determine their 'success'. Hence, further proving the concept of Festinger's (1954) Social Comparison Theory.

The theory of Impulse Buying, developed by Stern (1962), suggests that consumers generate an urge to purchase while in contact with the product (Stern, 1962) or otherwise, in the online context being evoked to purchase when in contact with images and comments on viral posts and online shops (Lo et al., 2016). The process is also often associated with an irrational purchase. However, the results of this study suggested that the process of impulse buying often still involves a logical decision.

The Affluenza Compulsive Buying Theory developed by Faber et al. (1987) suggests that consumers feel a form of gratification which eliminates negative thoughts about themselves when purchasing and consuming (McQueen et al., 2014). The findings of this study found that compulsive buying is often performed due to self-pamper and self-reward when interviewees mentioned that they often spend to reward themselves after accomplishing a challenging task or going through a tough period.

\section{Figure 1. The proposed framework of the study}

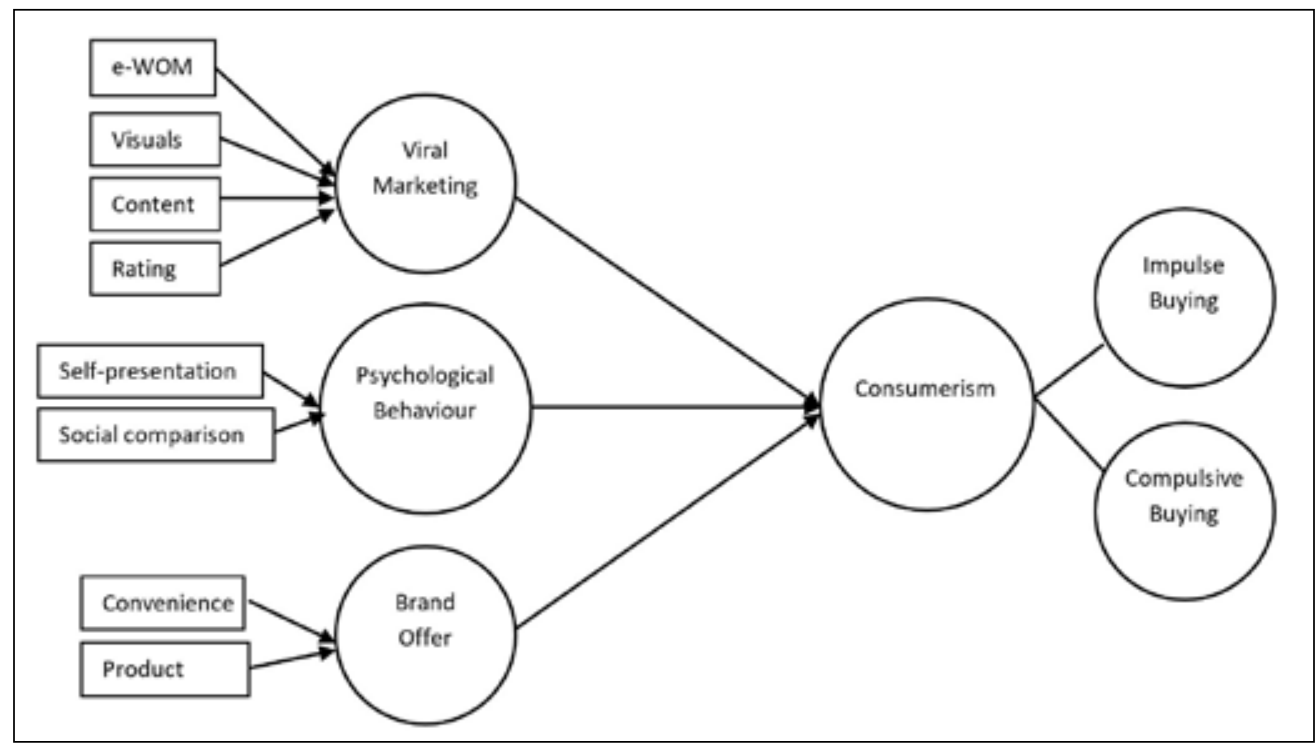

From this study, the ten themes identified have been categorized into four variables. E-WOM, visuals, content, and ratings are grouped as the factors of viral marketing. Self-presentation and social comparison are grouped as the multidimensions of psychological behaviour. While convenient and, products are grouped under brand offer. These three big variables contribute to the consumerism variable that is divided into two categories which are impulsive and 
compulsive buying. The proposed framework of the influence of viral marketing in SNSs on consumerism is conceptualised in Figure 1.

For the practical implications, due to its low cost and high rapid response rate, viral marketing has become one of the commonly used online marketing strategies today (Yang et al., 2011, as cited in Gunawan \& Huarng, 2015; Van der Lans \& Van Bruggen, 2011, as cited in Botha \& Reyneke, 2013). Hence, one of the practical implementations of this research would be to assist marketers on how to effectively utilize viral marketing tools. To name a few, SME corporations in Malaysia and SMEs from the food and beverage industry would especially relate to this study as the low cost and high response rate viral marketing tactic would help them save up a lot in terms of finances. Content, ratings, and visuals are three important elements of any viral marketing post that influence consumerism. The post should provide sufficient information with interesting visuals to attract consumers. Additionally, the rating through positive reviews on the product or service offered also works as word-of-mouth recommendations for the consumers.

\section{LIMITATIONS.}

Several limitations were discovered upon implicating and completing this study. The first is the concept of the study. As the study focuses on the influences of consumerism in the context of viral marketing in SNSs, other factors contributing to consumerism were not discussed in this study. Hence, it is suggested that future researchers could look into other factors such as image-sharing SCPs such as Instagram and Pinterest or even social media influencers that have shown great influence on SNSs users in terms of consumerism.

The second limitation is the methodology of the study. As most of the answers given by respondents were straightforward and repetitive, conducting the study in a quantitative method would allow the data to be generalized and would allow the data to be more persuasive and impactful.

The third limitation is the demographics of the interviewees. The majority of the interviewees were coincidentally female. Future researchers are suggested to conduct a study with an equal number of both genders as respondents as well as to conduct a comparison study between both genders to see if the results are in sync. Geographical limitations wise, as the research was conducted only within Klang Valley. Klang Valley is an urbanised location, where urban people tend to have a higher consumption rate compared to those of other states.

\section{CONCLUSION}

The results of this study concluded ten different themes that have been filtered and categorised accordingly. There are four main factors behind the influences of viral marketing in social networking sites on consumerism. They are e-WOM, visuals, content, and rating. Additionally, psychological behaviour (self-presentation and social comparison) and brand offer (convenience and product) also contribute to consumerism. For consumerism, two different qualities of consumerism of which impulse and compulsive buying were identified through the results of this study. Results have suggested that all factors of consumerism if performed individually do not have a strong effect on consumerism. Instead, a combination of a few or all factors mentioned above in a viral marketing post on SNSs, are likely to influence consumerism. 


\section{REFERENCES}

2016 Malaysia Digital Landscape. (2016). Malaysian Digital Association. http://www. malaysiandigitalassociation.org.my/wp-content/uploads/reports/2016/mda2016-malaysia-digital-landscape.pdf

Al-Kwifi, O. S., \& Ahmed, Z. U. (2015). An intellectual journey into the historical evolution of marketing research in brand switching behavior-past, present and future. Journal of Management History, 21(2), 172-193.

Bian, Q., \& Forsythe, S. (2012). Purchase intention for luxury brands: A cross cultural comparison. Journal of Business Research, 65 (10), 1443-1451.

Botha, E., \& Reyneke, M. (2013). To share or not to share: the role of content and emotion in viral marketing. Journal of Public Affairs, 13(2), 160-171.

Braun, V., Clarke, V., \& Weate, P. (2016). Using thematic analysis in sport and exercise research. In B. Smith, \& A. C. Sparkes (Eds.), Routledge handbook of qualitative research in sport and exercise (pp. 191-205). London: Routlegde.

Bronstein, J. (2013). Personal blogs as online presences on the internet: Exploring selfpresentation and self-disclosure in blogging. Aslib Proceedings, 65(2), 161-181.

Casey, S. (2017, January 17). 2016 Nielsen social media report. Nielsen. https://www.nielsen. com/us/en/insights/report/2017/2016-nielsen-social-media-report/

Chen, J. V., Su, B. C., \& Widjaja, A. E. (2016). Facebook C2C social commerce: A study of online impulse buying. Decision Support Systems, 83, 57-69.

Chiu, C. M., Wang, E. T., Fang, Y. H., \& Huang, H. Y. (2014). Understanding customers' repeat purchase intentions in $\mathrm{B} 2 \mathrm{C}$ e-commerce: the roles of utilitarian value, hedonic value and perceived risk. Information Systems Journal, 24(1), 85-114.

Dehghani, M., \& Tumer, M. (2015). A research on effectiveness of Facebook advertising on enhancing purchase intention of consumers. Computers in Human Behavior, 49, 597-600.

Erkan, I., \& Evans, C. (2016). The influence of eWOM in social media on consumers' purchase intentions: An extended approach to information adoption. Computers in Human Behavior, 61, 47-55.

Etikan, I., Musa, S. A., \& Alkassim, R. S. (2016). Comparison of convenience sampling and purposive sampling. American Journal of Theoretical and Applied Statistics, 5(1), 1-4.

Faber, R. J., O'Guinn, T. C., \& Krych, R. (1987). Compulsive Consumption. Advances in Consumer Research, 14, 132-135.

Festinger, L. (1954). A theory of social comparison processes. Human Relations, 7, 117-140.

Forbes, L. P. (2013). Does social media influence consumer buying behavior? An investigation of recommendations and purchases. Journal of Business $\mathcal{E}$ Economics Research, 11 (2), 107-112.

Gonzales, A. L, \& Hancock, J. T. (2011). Mirror, mirror on my Facebook wall: Effects of exposure to Facebook on self-esteem. Cyberpsychology, Behavior, and Social Networking, 14 (1-2), 79-83.

Goodman, L.A. (1961). Snowball sampling. The Annals of Mathematical Statistics, 32(1), 148170

Gunawan, D. D., \& Huarng, K. H. (2015). Viral effects of social network and media on consumers' purchase intention. Journal of Business Research, 68(11), 2237-2241. 
Hajli, M. N. (2014). A study of the impact of social media on consumers. International Journal of Market Research, 56 (3), 387-404.

Hinz, O., Skiera, B., Barrot, C., \& Becker, J. U. (2011). Seeding strategies for viral marketing: An empirical comparison. Journal of Marketing, 75(6), 55-71.

Hutter, K., Hautz, J., Dennhardt, S., \& Füller, J. (2013). The impact of user interactions in social media on brand awareness and purchase intention: The case of MINI on Facebook. Journal of Product \& Brand Management, 22(5/6), 342-351.

Ketelaar, P. E., Janssen, L., Vergeer, M., van Reijmersdal, E. A., Crutzen, R., \& van't Riet, J. (2016). The success of viral ads: Social and attitudinal predictors of consumer pass-on behavior on social network sites. Journal of Business Research, 69(7), 2603-2613.

Kim, W. G., Li, J. J., \& Brymer, R. A. (2016). The impact of social media reviews on restaurant performance: The moderating role of excellence certificate. International Journal of Hospitality Management, 55, 41-51.

Leow, C. (2015). Are we using social media to feed our ego. Astro Awani. http://english. astroawani.com/lifestyle/are-we-using-social-media-feed-our-ego-81100

Lo, L. Y. S., Lin, S. W., \& Hsu, L. Y. (2016). Motivation for online impulse buying: A twofactor theory perspective. International Journal of Information Management, 36(5), 759-772.

Malaysian Communications and Multimedia Commission. (2014). Communications and Multimedia: Pocket Books of Statistics. Malaysian Communications and Multimedia Commission. https://www.mcmc.gov.my/skmmgovmy/media/General/pdf/ SKMM-Q4-2014_BI_1.pdf

Malaysian Communications and Multimedia Commission. (2014). Communications and Multimedia: Pocket Books of Statistics. Malaysian Communications and Multimedia Commission. https://www.mcmc.gov.my/skmmgovmy/media/General/pdf/CM-Q42015_BI.pdf

Malaysian Communications and Multimedia Commission. (2016). Internet Users Survey 2016. Malaysian Communications and Multimedia Commission. https://www.mcmc.gov. my/skmmgovmy/media/General/pdf/IUS2016.pdf

McNally, R. C., Cavusgil, E., \& Calantone, R. J. (2010). Product innovativeness dimensions and their relationships with product advantage, product financial performance, and project protocol. Journal of Product Innovation Management, 27(7), 991-1006.

McQueen, P., Moulding R., \& Kyrios, M. (2014). Experimental evidence for the influence of cognitions on compulsive buying. Journal of Behaviorial Therapy E Experimental Psychiatria 45, 496-501.

Nabi, R. L., \& Keblusek, L. (2014). Inspired by hope, motivated by envy: Comparing the effects of discrete emotions in the process of social comparison to media figures. Media Psychology, 17(2), 208-234.

Niu, H. J. (2013). Cyber peers' influence for adolescent consumer in decision-making styles and online purchasing behavior. Journal of Applied Social Psychology, 43(6), 1228-1237.

Parakh, A., Bindal, S., \& Saldanha, A. (2016). Impulse buying behavior in adolescents. Imperial Journal of Interdisciplinary Research, 2 (4), 273-279.

Percy, W. H., Kostere, K., \& Kostere, S. (2015). Generic qualitative research in psychology. The Qualitative Report, 20 (2), 76-85. 
Pescher, C., Reichhart, P., \& Spann, M. (2014). Consumer decision-making processes in mobile viral marketing campaigns. Journal of interactive marketing, 28 (1), 43-54.

Phan, T. T. H., \& Vu, P. A. (2015). The impact of marketing mix elements on food buying behavior: a study of supermarket consumers in Vietnam. International Journal of Business and Management, 10(10), $206-215$.

Phelps, J. E., Lewis, R., Mobilio, L., Perry, D., \& Raman, N. (2004). Viral marketing or electronic word-of-mouth advertising: Examining consumer responses and motivations to pass along email. Journal of Advertising Research, 44(4), 333-348.

Pounders, K., Kowalczyk, C. M., \& Stowers, K. (2016). Insight into the motivation of selfie postings: impression management and self-esteem. European Journal of Marketing, 50 (9/10), 1879-1892.

Rahman, S. U., Khan, M. A., Iqbal, N. (2018). Motivations and barriers to purchasing online: Understanding consumer responses, South Asian Journal of Business Studies, doi:10.1108/ SAJBS-11-2016-0088

Sani, R. (2017). Facebook is most used social media platform by M'sian students: Survey. New Straits Times. https://www.nst.com.my/education/2017/06/246209/facebook-mostused-social-media-platform-msian-students-survey.

Seidman, G. (2013). Self-presentation and belonging on Facebook: How personality influences social media use and motivations. Personality and Individual Differences, 54(3), 402-407.

Stern, H. (1962). The significance of impulse buying today. Journal of Marketing, 26, 59-62.

Thoumrungroje, A. (2014). The influence of social media intensity and EWOM on conspicuous consumption. Procedia-Social and Behavioral Sciences, 148, 7-15.

Trandafilović, I., Pašić, V., \& Perunović, S. (2013). The research of cognitive and affective behaviour during shopping. Economics and Organization, 10(2), 147-164.

Wheeless, L. R. (1978). A follow-up study of the relationships among trust, disclosure, and interpersonal solidarity. Human Communication Research, 4, 143-157.

Wimmer, R.D \& Dominick J.R (2014). Mass media research: An Introduction (10 ${ }^{\text {th }}$ ed.). Cengage Learning Asia Pte Ltd, Singapore.

Xiang, L., Zheng, X., Lee, M. K., \& Zhao, D. (2016). Exploring consumers' impulse buying behavior on social commerce platform: The role of parasocial interaction. International Journal of Information Management, 36(3), 333-347.

Yang, H., Liu, H., \& Zhou, L. (2012). Predicting young Chinese consumers' mobile viral attitudes, intents and behavior. Asia Pacific Journal of Marketing and Logistics, 24 (1), 59-77.

Yen, Y. S. (2016). Factors enhancing the posting of negative behavior in social media and its impact on venting negative emotions. Management Decision, 54(10), 2462-2484.

Zulfagharifard, E. (2015). 75\% of People say they fake how exciting their lives are on Facebook. Daily Mail. http://www.dailymail.co.uk/sciencetech/article-3274749/Welcome-Fakebook75-people-admit-making-lives-exciting-social-media.html 